\title{
Genetic Evidence of Postglacial Population Expansion in Puget Sound Rockfish (Sebastes emphaeus)
}

\author{
Erik E. Sotka, ${ }^{1,2}$ Jennifer A. Hempelmann, ${ }^{1,3}$ Christiane H. Biermann ${ }^{1,4}$ \\ ${ }^{1}$ University of Washington, Friday Harbor Laboratories, Friday Harbor, WA 98250, USA \\ ${ }^{2}$ Grice Marine Laboratory, Department of Biology, College of Charleston, Charleston, SC 29412, USA \\ ${ }^{3}$ Northwest Fisheries Science Center, NOAA, Montlake Boulevard East, Seattle, WA 98112, USA \\ ${ }^{4}$ Department of Biology, Portland State University, Portland, OR 97207-0751, USA
}

Received: 25 March 2004 / Accepted: 12 July 2004 / Online publication: 5 May 2005

\begin{abstract}
Several rockfish species (genus Sebastes) along the northeastern Pacific Ocean have rapidly declined in abundance owing in part to overfishing. A striking exception is the dwarf-like Puget Sound rockfish Sebastes emphaeus, whose densities have increased by several orders of magnitude over the last several decades. To describe their genetic structure, we sequenced $395 \mathrm{bp}$ from the mitochondrial control region of $128 \mathrm{~S}$. emphaeus adults from 5 locations spanning approximately $120 \mathrm{~km}$ of the Northwest Straits of Washington state. We detected no significant genetic differentiation among these populations and substantial genetic variation within populations, a pattern that may indicate high levels of ongoing gene flow. Preliminary data from 2 microsatellite loci are also consistent with panmixia. The mtDNA sequences also suggest that Puget Sound rockfish populations have expanded substantially since the retreat of Pleistocene glaciers made habitat in Puget Sound region available approximately 12,000 years ago.
\end{abstract}

Key words: population expansion - Pleistocene mitochondrial control region - microsatellite DNA - gene flow

\section{Introduction}

Intense research efforts have focused on the biology, ecology, and conservation of rockfishes (genus Sebastes). This speciose genus (at least 102 species) represents a remarkable marine radiation that has yielded a diversity of morphologies, life histories, and

Correspondence to: Erik E. Sotka; E-mail: sotkae@cofc.edu habitat specificities (Love et al., 2002). Historically, rockfishes and other large vertebrates have played fundamental roles in the ecology of nearshore communities in the northeast Pacific (Dayton et al., 1998). Although fishes with longer life histories make poor candidates for sustainable harvesting, a popular recreational and commercial fishery of rockfish arose in the late 1960s and early 1970s and peaked at over 200 million tons in the early 1990s along the west coast of North America (Laidig et al., 1996; Love et al., 2002). Largely as a consequence of these harvests, the ecologically and commercially important large rockfish species began a precipitous decline to a fraction of their original biomass (Gunderson, 1997).

In Puget Sound, Washington, a substantial recreational fishery diminished populations of several large rockfish species (e.g., copper, quillback, and brown rockfish; Pacunksi and Palsson, 2001) over only 3 decades. In stark contrast to declines in the large rockfishes, a dwarf-like rockfish that has no commercial value or recreational interest - the $\mathrm{Pu}$ get Sound rockfish Sebastes emphaeus - exploded in population size by several orders of magnitude over the same time period (D.R. Gunderson and B.S. Miller, unpublished manuscript). Relative to other Sebastes species, Puget Sound rockfish are small and have a relatively short life span. The average length of 3- to 5-year-old adult Puget Sound rockfish is 13 to 16 $\mathrm{cm}$, but older fish may reach up to $18 \mathrm{~cm}$ in length (Beckmann et al., 1998). Female Puget Sound rockfish reach sexual maturity at approximately 1.87 years of age and exhibit high fecundity, averaging 35,723 eggs per spawning season. The concern for managers is that huge aggregations of these small rockfish may impede the recovery of larger and more commercially valuable rockfishes.

Sebastes emphaeus is closely related to $S$. variegatus (harlequin rockfish) and S. zacentrus (sharp- 
chin rockfish; Rocha-Olivares et al., 1999). Fertilization is internal, and after insemination sperm is stored up to several months in the ovary. The developing eggs, embryos, and early larval stages are protected inside the female body for a 30-day gestation period until they are born as relatively advanced young (Beckmann et al., 1998). Although most other northeastern Pacific Sebastes species release their young between January and July, Puget Sound rockfish have a relatively short spawning season at the end of August and the beginning of September, lasting only 9 days. Because of this delayed and short spawning season, the possibility that Puget Sound rockfish interbreed with other Sebastes species is low.

We have used genetic tools to quantify gene flow and dispersal among Puget Sound rockfish populations separated by 10 to $120 \mathrm{~km}$. Puget Sound rockfish are live-bearers. During a larval and early juvenile stages they stays in the water column from 2 to 6 months, a life history that suggests widespread larval dispersal and gene flow (Buonaccorsi et al., 2002). Alternatively, larval dispersal distances may be more limited than suggested by the extended larval period, because of retention of water masses within enclosed estuaries, larval behavior, or some mix of ecologic forces (Grosberg and Cunningham, 2001; Shanks, 1995). We also analyzed DNA sequences for a genetic signature of recent population expansion.

\section{Materials and Methods}

Collection and Extraction of DNA from Adult Sebastes emphaeus. Approximately 30 to 40 adult fish were collected by hook and line and scuba between
April 9 and May 26, 2003, from each of 4 locations in the San Juan Islands and one location in central Puget Sound (Figure 1). All fish were collected at between 50 and 175 feet depth. A small section of white muscle tissue was removed just anterior to the caudal peduncle and preserved in 95\% ethanol. Approximately $1-\mathrm{mm}^{3}$ bits of tissue were extracted using $150 \mu \mathrm{l}$ of $10 \%$ Chelex 100 Resin solution (BioRad, 100-200 mesh Chelex, sodium form) heated at $95^{\circ} \mathrm{C}$ for 20 minutes. Sample DNA was stored at $-20^{\circ} \mathrm{C}$ when not in use.

\section{Amplification and Sequencing of Mitochondrial} DNA. Approximately 395 bp of the transfer RNA Pro and D-loop loci in the mitochondrial genome were amplified and sequenced using the primers L15924 (5'-AGC TCA GCG CCA GAG CGC CGG TCT TGT AAA-3'; Kocher et al., 1993) and H16498 (5'-CCT GAA GTA GGA ACC AGA TG-3': Meyer et al., 1990). The first base pair on the $5^{\prime}$ end of the sequence corresponds to base pair 15571 of the complete mitochondrial sequence of Helicolenus hilgendorfi (NCBI accession number NC_003195). Polymerase chain reaction (PCR) cycling conditions included an initial denaturation of 90 seconds at $94^{\circ} \mathrm{C}, 30$ cycles of $94^{\circ} \mathrm{C}$ for 30 seconds, $54^{\circ} \mathrm{C}$ for 30 seconds, and $72^{\circ} \mathrm{C}$ for 45 seconds, and a final extension step at $72^{\circ} \mathrm{C}$ for 5 minutes. The 25- $\mu$ l PCR reaction included $2.0 \mu \mathrm{l}$ Chelex-extracted DNA. $1.6 \mathrm{mM} \mathrm{MgCl}, 0.2 \mathrm{mM}$ dNTPs, $1 \mathrm{mM}$ Tris (pH 8.3), $5 \mathrm{mM} \mathrm{KCl}, 0.5 \mu \mathrm{M}$ of each primer, and $0.315 \mathrm{U}$ of Taq polymerase.

PCR products were visualized on $1.5 \%$ agarose gels stained with ethidium bromide. Each amplified PCR product was prepared for sequencing using shrimp alkaline phosphatase (SAP) and exonuclease I

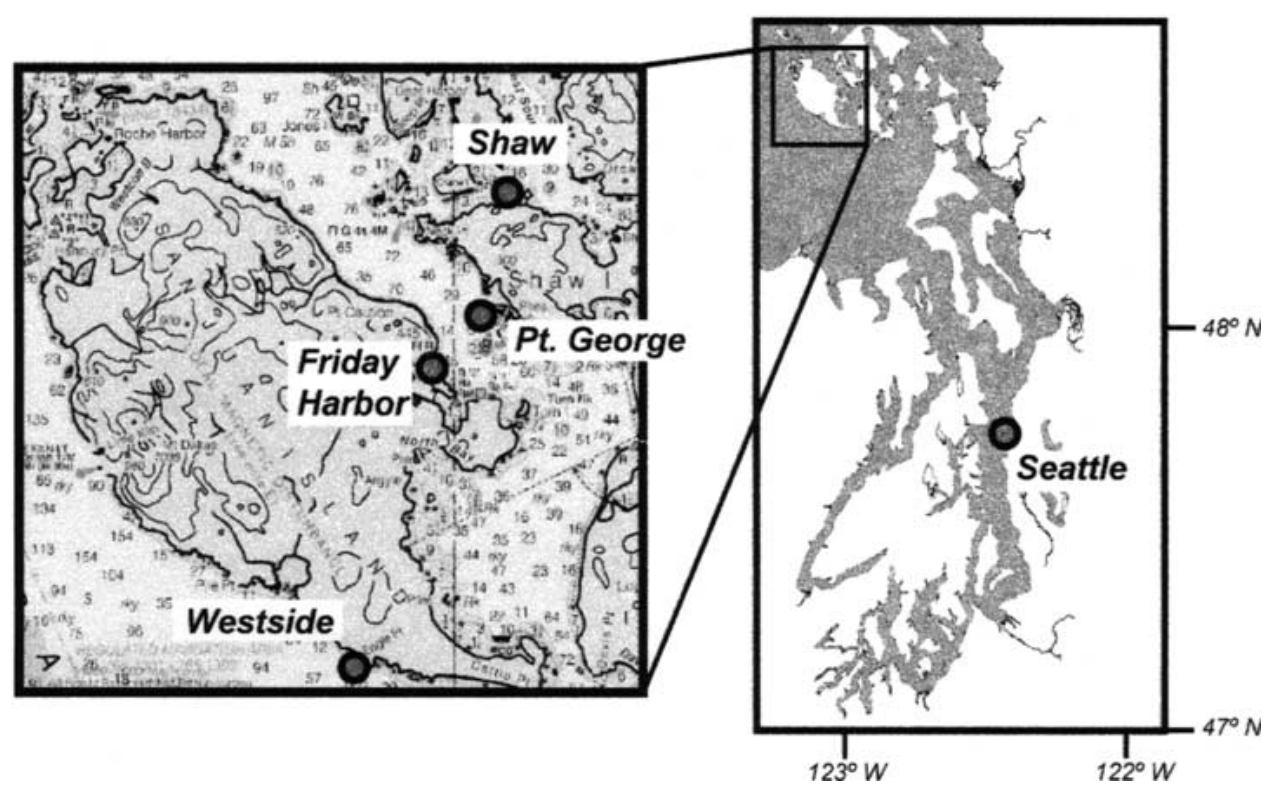

Fig. 1. Collection sites. Four locations in the San Juan Islands (Westside $\left[48^{\circ} 29.119^{\prime} \mathrm{N}\right.$ $\left.\left.123^{\circ} 05.823^{\prime} \mathrm{W}\right]\right)$; Friday Harbor $\left[48^{\circ} 33.192^{\prime} \mathrm{N} 123^{\circ} 00.397^{\prime} \mathrm{W}\right]$; Pt. George $\left[48^{\circ} 33.529^{\prime} \mathrm{N}\right.$ $122^{\circ} 59.323^{\prime} \mathrm{W}$ ); and Shaw Island $\left[48^{\circ} 35.44^{\prime} \mathrm{N}\right.$ $\left.\left.122^{\circ} 57.56^{\prime} \mathrm{W}\right]\right)$ were separated by approximately 2 to $20 \mathrm{~km}$ from each other and separated from the central Puget Sound location (Seattle $\left[47^{\circ} 41.94^{\prime} \mathrm{N}\right.$ $\left.122^{\circ} 23.20^{\prime} \mathrm{W}\right]$ ) by approximately $100 \mathrm{~km}$. 
(Exo) enzymes (1.25 $\mu$ l dilution buffer, 0.5 U SAP, 2 U Exo, and $5 \mu$ l PCR product). The SAP-Exo reaction was carried out at $37^{\circ} \mathrm{C}$ for 30 minutes followed by $80^{\circ} \mathrm{C}$ for 15 minutes. DNA products were cycle-sequenced using the ABI PRISM BigDye sequencing kit (Applied Biosystems), purified with a Sephadex column, and electrophoresed with an ABI377 DNA sequencer. Sequences were edited in SEQUENCHER Version 4.1 and aligned in CLUSTAL X Version 1.64 (Thompson et al., 1997).

\section{Amplification and Genotyping of Microsatellite} Loci. Two microsatellite loci that were first isolated from a genomic library of the quillback rockfish Sebastes maliger (Wimberger et al., 1999) were analyzed. The first locus, Sma2, was amplified using primers (5'-CACAGGACTATCAGCAGGGAAG-3') and (5'-1 HeX/TTACTTGTTTTCTTTGTCTCATGTGG-3'). The second locus, Sma4, was amplified using primers $\left(5^{\prime}\right.$ CAAATTGCCCCCACTGAAG- $\left.3^{\prime}\right)$ and (5'-/TAMRA/CATAACATATGATGGAAAATAAAACCC-3'). The Sma2 (dinucleotide repeats) and Sma4 (triucleotide repeats) amplified regions were 166 to $184 \mathrm{bp}$ and 205 to 220 bp, respectively.

The Sma2 locus, was PCR-amplified using an initial denaturation step of $94^{\circ} \mathrm{C}$ for 90 seconds, 36 cycles of $94^{\circ} \mathrm{C}$ for 20 seconds, $58^{\circ} \mathrm{C}$ for 30 seconds, and $72^{\circ} \mathrm{C}$ for 20 seconds, and a final extension step of $72^{\circ} \mathrm{C}$ for 5 minutes. The cycling conditions for Sma4 locus were identical except that the annealing temperature was $54^{\circ} \mathrm{C}$. Standard PCR conditions were the same for both loci $(2.0 \mu 1$ Chelex-extracted DNA, $2.5 \mu$ PCR reaction buffer, $1.5 \mathrm{mM} \mathrm{MgCl} 2,0.2 \mathrm{mM}$ dNTP, $0.5 \mu \mathrm{M}$ of each primer, 0.2 U Taq DNA polymerase, and $\mathrm{H}_{2} \mathrm{O}$ up to $25.0 \mu \mathrm{l}$ total). PCR products were visualized on $2.5 \%$ agarose gels stained with ethidium bromide. Microsatellite genotyping was done using the ABI377 in GeneScan mode. An aliquot of $0.5 \mu \mathrm{l}$ of each PCR sample was loaded onto 36$\mathrm{cm}$ polyacrylamide gels and scanned simultaneously with $0.8 \mu$ l ROX-internal sizing standard. The ABI gel file data were analyzed using the GeneScan program, and microsatellite lengths were assessed relative to size standards using ABI Genotyper.

Data Analysis. Sequences were deposited in GenBank under accession numbers AY577587 to AY577719. A neighbor-joining tree of mtDNA haplotypes was generated in MEGA 2.0 (Kumar et al., 2001) using a model of substitution suggested by ModelTest $\left(\mathrm{K} 80 ; \mathrm{Ti} / \mathrm{TV}_{V}=4.025\right.$, equal base frequency; Posada and Crandall, 1998), and using an outgroup (see below) to root the tree. Statistical support for the tree structure was determined using 10,000 bootstrap replicates in PAUP.
Estimates of population differentiation $\left(\mathrm{F}_{\mathrm{st}}\right)$ and standard diversity indices were generated for both mtDNA and microsatellite data using an analysis of molecular variance (AMOVA) test performed by the computer program ARLEQUIN (Schneider et al. 2000). We also used ARLEQUIN to perform Tajima's $D$, Fu's $F$, and mismatch distribution tests, and evaluated each test statistic using 10,000 Monte Carlo replicates.

\section{Results}

Diversity of mtDNA Sequences in Sebastes emphaeus. There is substantial genetic variation within the control region locus of Sebastes emphaeus. Fiftysix haplotypes - only 16 of which were shared by 2 or more individuals - were sequenced from 128 individuals (Figure 2). Nucleotide diversity (p) was estimated at $1.0 \% \pm 0.1 \%($ mean $\pm \mathrm{SD}$; Table 1$)$. Six individuals contained a 1-bp deletion at position 389; this appeared to have been an ancient substitution as the sequences differed at other positions. Five individuals of an unknown species were sequenced from a population on the westside of San Juan Island. These were morphologically similar to $S$. emphaeus but had sequences that differed by nearly $4 \%$ from $S$. emphaeus (Figure 2). These sequences were excluded from the population genetic analyses.

Phylogenetic analysis indicates 2 major clades (denoted A and B) within S. emphaeus, distinguished by 2 transitions (positions 11 and 97) and one transversion (position 187; Figure 3). There is $70 \%$ bootstrap support at this node. The tree was constructed using a K80 model of evolution (Ti/Ty ratio $=4.03$; equal base frequencies; equal rates of substitution among sites) and rooted to the unknown species in our collection.

Genetic Population Structure of Sebastes emphaeus. There is little evidence for population subdivision across localities separated by up to approximately $120 \mathrm{~km}$ in Puget Sound and the San Juan Islands. An analysis of the control region sequences found no significant differences in the frequencies of the 16 shared haplotypes $\left(\Sigma^{2}=46.82\right.$, $d f=60, P=0.893$; see Figure 2 for frequencies) and no differences in the relative proportions of the 2 control region clades (Figure 3; $G=7.363, d f=4$, $P=0.498$; see Table 1 for frequencies). AMOVA indicated no significant differentiation among populations $\left(\mathrm{F}_{\mathrm{st}}=-0.012, P=0.855\right)$; the negative $\mathrm{F}_{\mathrm{st}}$ reflects the fact that more variance exists within than across populations.

An analysis of 2 microsatellite loci, which presumably evolve more quickly than mtDNA /Sekino 


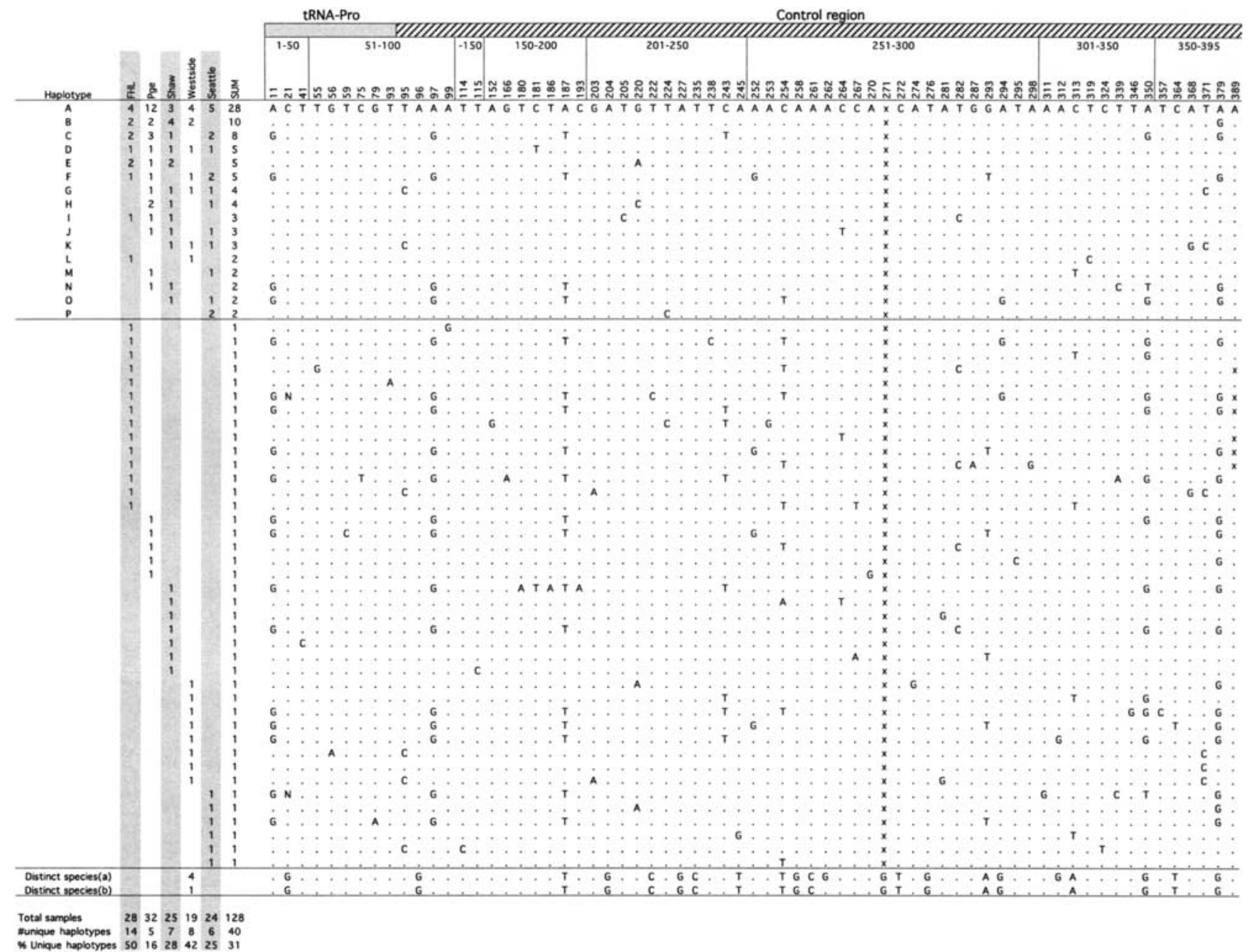

Fig. 2. Haplotypes of mtDNA control region among populations of the Puget Sound rockfish Sebastes emphaeus. Numbers on the left indicate frequencies of each haplotype. An " $x$ " indicates an indel and a dot indicates that the base pair is identical to haplotype A. Numbers along the top indicate the base pair location.

et al., 2001), also revealed no significant population subdivision. AMOVA detected no significant differentiation when both loci were analyzed simultaneously $\left(\mathrm{F}_{\mathrm{st}}=0.025 ; P=0.143\right)$ or were analyzed singly $\quad\left(\right.$ Sma2, $\quad \mathrm{F}_{\mathrm{st}}=-0.002, \quad P=0.520 ; \quad$ Sma4, $\left.\mathrm{F}_{\mathrm{st}}=0.045, P=0.106\right)$. For all populations, alleles of Sma2 were distributed in Hardy-Weinberg equilib- rium while fewer heterozygotes than expected by HWE were detected at Sma4 (Table 1).

\section{Discussion}

An examination of mitochondrial and nuclear microsatellite loci reveals that populations of the $\mathrm{Pu}$ -

Table 1. Indices of Genetic Diversity, Haplotye Frequencies, and Tests for Population Expansion Among Populations of the Puget Sound Rockfish Sebastes emphaeus.

\begin{tabular}{|c|c|c|c|c|c|c|c|c|c|}
\hline \multirow[b]{2}{*}{ Population } & \multirow[b]{2}{*}{$n$} & \multirow{2}{*}{$\begin{array}{l}\text { Number of } \\
\text { haplotypes }\end{array}$} & \multirow{2}{*}{$\begin{array}{l}\text { Number of } \\
\text { unique } \\
\text { haplotypes }\end{array}$} & \multirow{2}{*}{$\begin{array}{l}\text { Proportions of } \\
\text { clades }(A: B)\end{array}$} & \multirow{2}{*}{$\begin{array}{l}\text { Nucleotide diversity } \\
( \pm \text { S.D. })\end{array}$} & \multicolumn{2}{|c|}{ Tajima's D test } & \multicolumn{2}{|c|}{ Fu's F test } \\
\hline & & & & & & $D$ & P-value & Fs & $P$-value \\
\hline FHL & 28 & 22 & 14 & $0.71: 0.29$ & $0.012( \pm 0.002)$ & & & & \\
\hline Pge & 32 & 17 & 5 & $0.78: 0.22$ & $0.008( \pm 0.003)$ & & & & \\
\hline Shaw & 25 & 20 & 7 & $0.80: 0.20$ & $0.010( \pm 0.002)$ & & & & \\
\hline Westside & 19 & 15 & 8 & $0.79: 0.21$ & $0.012( \pm 0.002)$ & & & & \\
\hline Seattle & 23 & 17 & 6 & $0.70: 0.30$ & $0.012( \pm 0.002)$ & & & & \\
\hline TOTAL & 127 & 56 & 40 & $0.76: 0.24$ & $0.01( \pm 0.001)$ & -2.03 & $P=0.021$ & -47.91 & $P<0.001$ \\
\hline
\end{tabular}




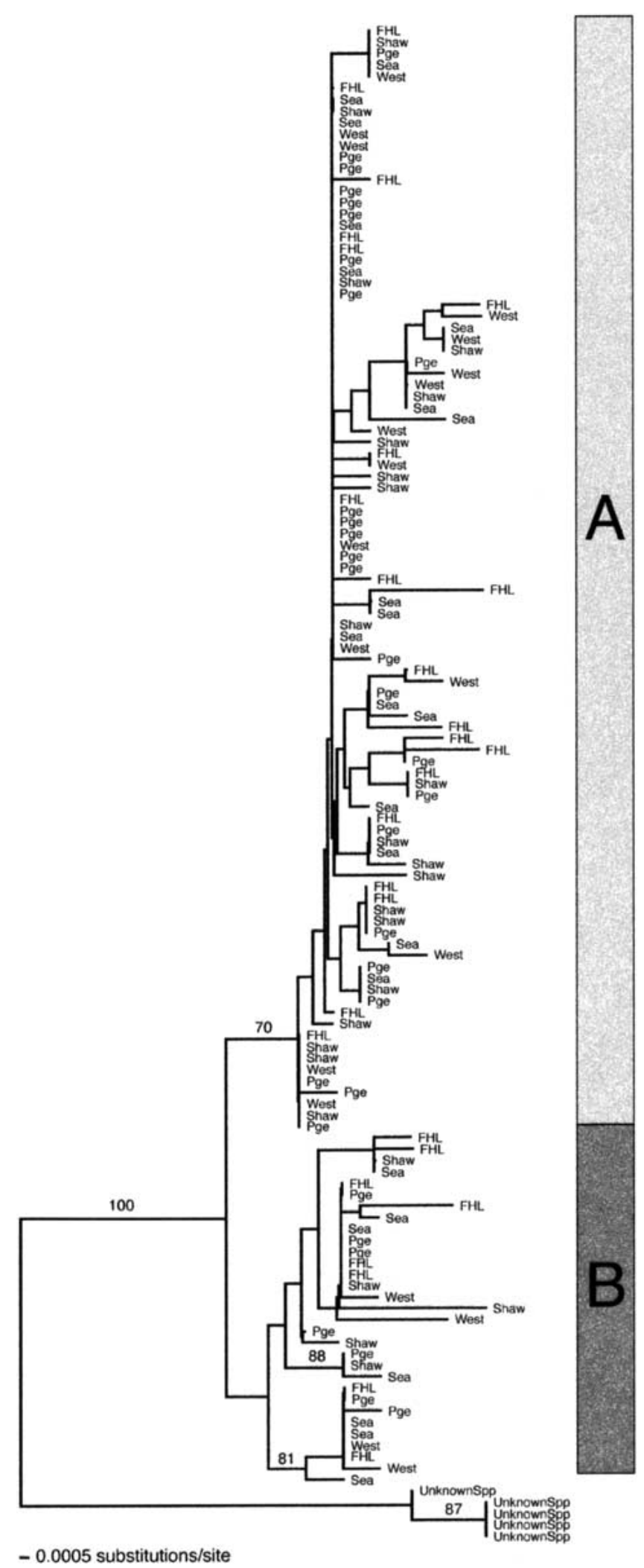

Fig. 3. Neighbor-joining tree of mtDNA control region haplotypes taken from individuals at 5 locations in the Northwest Straits and Puget Sound. Numbers indicate the bootstrap support for each node from 10,000 bootstrap replicates. Five unknown species were sequenced and used as outgroup taxa. FHL indicates Friday Harbor Laboratories; Pge, Pt. George; Sea, Seattle; West, Westside.

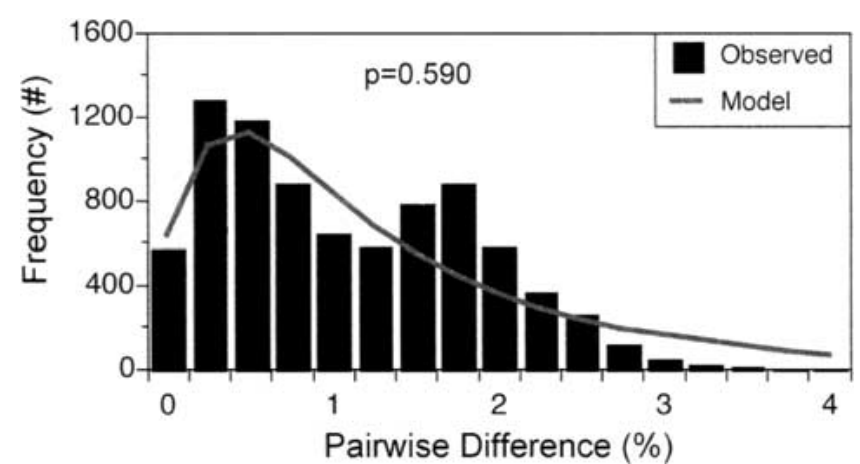

Fig. 4. Mismatch distribution of mtDNA control region haplotypes. The continuous line represents the distribution expected from recent demographic expansion. There is no significant difference between observed and expected distributions, as assessed by an analysis of sum-of-squared differences using a parametric boostrap with 10,000 replicates (Schneider et al., 2000).

get Sound rockfish Sebastes emphaeus have substantial genetic variation within populations (Figures 1-3). The 2 major control region clades (Figure 1) occurred at all locations in a approximately 70:30 mix (Table 1). Heterozygosity levels were high at the Sma2 microsatellite locus, though the Sma4 locus had a significantly lower amount of heterozygosity relative to expectations (Table 1). We have no information on whether this indicates the presence of null alleles or selection on a linked locus.

Despite the ample degree of genetic variation, no significant amount of genetic variation was partitioned across populations at either control region or microsatellite loci. Because the noncoding control region locus is unlikely to be under selection, and because all 3 loci show the same pattern, genetic homogeneity among populations is the consequence of broad gene flow among populations, or a recent cessation of gene flow and incomplete lineage sorting. We contend that there is abundant genetic exchange among rockfish populations separated by 10 to $120 \mathrm{~km}$ in the Northwest Straits, since even the more quickly evolving microsatellite loci displayed no genetic differentiation with reasonable sample sizes $(n=15$ to 27 per locus per population). A more definitive conclusion may be reached with higher sample sizes and more loci.

The lack of genetic subdivision is somewhat surprising, given that Buonaccorsi et al. (2002) used microsatellites from the copper rockfish (Sebastes caurinus) to document genetic differences between Puget Sound populations and a single population in the Canadian Gulf Islands, which is less than 100 $\mathrm{km}$ north of our San Juan Island locations. It is 
also possible that genetic differences will be revealed by comparing $S$. emphaeus populations in the Puget Sound with those on the outer coast, as has been documented in a number of rockfish species (e.g., Davis et al, 1981; Seeb, 1998; Hickerson and Ross, 2001; Buonaccorsi et al., 2002). Our future efforts will include populations from these other locations and more genetic loci in order to test for similar barriers to gene flow in $S$. emphaeus.

The mtDNA sequence data contain a signal of population expansion that appears to reflect a relatively old expansion into the Puget Sound region. Analysis of the mitochondrial control region data indicated more "new" mutations than would be expected from the number of segregating sites (Tajima's $D=-2.03, P=0.021$ ) of from the number of alleles (Fu's $F=-47.91, P<0.001$; Table 1). Because it is unlikely that the noncoding locus is under selection, these negative $D$ and $F$ values likely indicate an expanding population.

Population expansion is confirmed by an analysis of the frequency distribution of pairwise differences between individual sequences (i.e., mismatch distribution). The distribution of mismatches cannot be statistically differentiated from a unimodal distribution (Figure 4; $P=0.590$ ), a pattern consistent with demographic expansion (Rogers and Harpending, 1992). However, we infer such unimodality with caution because visual evaluation of the mismatch distribution suggests that it may be multimodal and more consistent with a stable, demographic equilibrium.

If we assume the mismatch distribution is unimodal, then we can use the mismatch distribution analysis to approximate the timing of the beginning of the expansion. The software ARLEQUIN uses a nonlinear least-square analysis of the mismatch distribution to generate an empirical estimate of $\mathrm{t}$ (Schneider et al., 2000), which is equivalent to $2 \mu \mathrm{T}$ where $\mu$ is the mutation rate and $T$ is the time since expansion started (for example see Harpending et al., 1994; Lessios et al., 2001). Unfortunately, there are no fossil-calibrated molecular clocks for this genus, so we assumed the mitochondrial control region evolves at a rate of $0.08 \%$ per million years as suggested by a phylogenetic survey of the subgenus Sebastomus (Rocha-Olivares et al., 1999). Because ARLEQUIN estimates $t=0.908$, we infer that the time since the expansion began in Puget Sound is approximately 12,770 years before present, almost exactly at the end of the last glaciation. However, the $95 \%$ confidence intervals for this estimate are extremely broad, suggesting that expansion could have begun in the last decade or up to 86,000 years ago $\left(95 \% \mathrm{CI},\left[0.0,8.6 \times 10^{4}\right]\right)$. A $90 \%$ confidence interval indicates the expansion could have begun 1336 to 65,963 years ago. The notion that expansion began approximately 12,000 years ago matches very closely with estimates of when estuarine habitats became available in the Puget Sound area and the Northwest Straits basin (Pielou, 1991). Thus the body of evidence is consistent with an expansion of S. emphaeus into Puget Sound since the retreat of the last glacial maxima.

The assumptions underlying these estimates are error-prone, but would likely generate an underestimation bias rather than an overestimate of the age of Puget Sound populations (Lessios et al., 2001). In particular, we assume that the sampled populations are not subdivided and the control region locus is not under selection. We detected no evidence for strong subdivision in the microsatellite loci, though these are preliminary results. The noncoding control region is unlikely to be under direct selection, though the mitochondria is inherited as one unit, and thus selection could act on other mitochondrial loci and affect the evolution of the control region. If subdivision was rampant and diversifying selection was strong, the population size and the age since expansion inferred from the genetic diversity would be greater than the true values.

Our genetic analyses were meant to help distinguish between two hypotheses put forward to explain the apparent population expansion of Puget Sound rockfish in recent decades. Both hypotheses are based on the severe depletion of the stocks of the larger local marine fish: either the Puget Sound rockfish populations truly exploded when niche space opened up, or they just moved from deeper to shallower water when competition with the larger species disappeared. The time scale of the population expansion that our genetic data bear out cannot distinguish between the two hypotheses. Even the fastest-evolving region of the mtDNA, the D-loop, does not resolve mutation patterns on a scale of a few decades, but rather reflects demographic changes due to colonization into the Northwest Straits after the last ice age.

In summary, we have detected apparently high gene flow among populations of Puget Sound rockfish in Washington's Northwest Straits and detected a genetic signal of population expansion that was likely initiated with the postglacial colonization of the Puget Sound region about 12,000 years ago. The most pressing work that remains is to assess whether the surprisingly high densities of this "dwarf" rockfish may alter the course of recovery of the larger, commercially valuable species. In particular, a focus on the feeding ecologies and interactions 
among adult Puget Sound rockfish and juvenile individuals of the larger rockfish species (i.e., chopper, brown, and quillback rockfish) should reveal whether these fish guilds compete for food and habitat and thus whether such competition may impede a rapid recovery of the larger rockfish. Alternatively, if there is no competition, and if the larger rockfish simply need time to rebound in population size, then these large abundances of Puget Sound rockfish may actually accelerate recovery of larger rockfish because Puget Sound rockfish are reportedly prey of larger rockfishes (Love et al., 2002).

\section{Acknowledgments}

This project was generated during a Spring 2003 Research Apprenticeship Course at Friday Harbor Laboratories (University of Washington). J.H. received financial support from the Mary Gates Endowment. E.S. was supported in part by the Andrew W. Mellon Foundation. We thank D. Halos, R. Buckley, and the Washington Department of Fish and Wildlife for help with fishing.

\section{References}

1. Beckmann AT, Gunderson DR, Miller BS, Buckley RM, Goetz B (1998) Reproductive biology, growth, and natural mortality of Puget Sound rockfish, Sebastes emphaeus. Fish Bull 96, 352-356

2. Buonaccorsi VP, Kimbrell CA, Lynn EA, Vetter RD (2002) Population structure of copper rockfish (Sebastes caurinus) reflects postglacial colonization and contemporary patterns of larval dispersal. Can J Fish Aquat Sci 59, 7374-1384

3. Davis BJ, Demartini EE, McGee K (1981) Gene flow among populations of a teleost (painted greenling, Oxylebius pictus) from Puget Sound to southern California, USA. Mar Biol (Berlin) 65, 17-24

4. Dayton PK, Tegner MJ, Edwards PB, Riser KL (1998) Sliding baselines, ghosts, and reduced expectations in kelp forest communities. Ecol Appl 8, 309-322

5. Grosberg RK, Cunningham CW (2001) "Genetic structure in the sea: from populations to communities". In: Marine Community Ecology, Bertness MD, Gaines S, Hay ME, eds. (Sunderland, Mass: Sinauer Associates) pp 61-84

6. Gunderson DR (1997) Spatial patterns in the dynamics of slope rockfish stocks and their implications for management. Fish Bull 95, 219-230

7. Hickerson M, Ross J (2001) Post-glacial population history and genetic structure of the northern clingfish (Gobiesox maeandricus) revealed from mtDNA analysis. Mar Biol 138, 407-419
8. Kocher TD, Conroy JA, McKaye KR, Stauffer JR (1993) Similar morphologies of cichlid fish in Lakes Tanganyika and Malawi are due to convergence. Mol Phylogenet Evol 2, 158-165

9. Kumar S, Tamura K, Jakobsen IB, Nei M (2001) MEGA2: Molecular Evolutionary Genetics Analysis software. Bioinformatics 17, 1244

10. Laidig TE, Sakuma KM, Nishimoto MN (1996) Description of pelagic larval and juvenile stripetail rockfish, Sebastes saxicola (family Scorpaenidae), with an examination of larval growth. Fish Bull 94, 289-299

11. Lessios HA, Garrido MJ, Kessing BD (2001) Demographic history of Diadema antillarum, a keystone herbivore on Caribbean reefs. Proc R Soc Lond B 268, 2347-2353

12. Love MS, Yoklavich M, Thorsteinson L (2002) The Rockfishes of the Northeast Pacific Berkeley, University of California Press

13. Meyer A, Kocher TD, Basasibwaki P, Wilson AC (1990) Monophyletic origin of Lake Victoria cichlid fishes suggested by mitochondrial DNA sequences. Nature 347, 550-553

14. Pacunski, RE, and Palsson, WA (2001) Macro- and micro-habitat relationships of adult and sub-adult rockfish, lingcod, and kelp greenling in Puget Sound In: Puget Sound Research '01 Proceedings Olympia, Wash: Puget Sound Water Quality Action Team

15. Pielou EC (1991) After the ice age: the return of life to glaciated North America. (Chicago: University of Chicago Press) p 376

16. Posada D, Crandall KA (1998) MODELTEST: testing the model of DNA substitution. Bioinformatics 14, $817-818$

17. Rocha-Olivares A, Kimbrell CA, Eitner BJ, Vetter RD (1999) Evolution of a mitochondrial cytochrome $b$ gene sequence in the species-rich genus Sebastes (Teleostei, Scorpaenidae) and its utility in testing the monophyly of the subgenus Sebastomus. Mol Phylogenet Evol 11, 426-440

18. Rogers AR, Harpending H (1992) Population growth makes waves in the distribution of pairwise genetic differences. Mol Biol Evol 9, 552-569

19. Schneider S, Roessli D, Excoffier L (2000) ARLEQUIN Version 2000: A Software for Population Genetics Data Analysis. (Geneva, Switzerland: Genetics and Biometry Laboratory, University of Geneva)

20. Seeb LW (1998) Gene flow and introgression within and among three species of rockfishes, Sebastes auriculatus, S. caurinus and S. maliger. J Hered 89, 393403

21. Sekino M, Takagi N, Hara M, Takahashi H (2001) Analysis of microsatellite DNA polymorphisms in rockfish Sebastes thompsoni and application to population genetics studies. Mar Biotechnol 3, 4552

22. Shanks A (1995) "Mechanisms of cross-shelf dispersal of larval invertebrates". In: Ecology of Marine Invertebrate Larvae, McEdward L, ed. (Boca Raton, Fla: CRC Press) pp 323-368 
23. Thompson JD, Gibson TJ, Plewniak F, Jeanmougin F, Higgins DG (1997) The CLUSTAL X Windows Interface: flexible strategies for multiple sequence alignment aided by quality analysis tools. Nucleic Acids Res 25, 4876-4882
24. Wimberger P, Burr J, Gray A, Lopez A, Bentzen P (1999) Isolation and characterization of twelve microsatellite loci for rockfish (Sebastes). Mar Biotechnol 1, 311-315 